\title{
Site Specific Application of Neem Coated Urea for Cotton Crop - A Lab Study
}

\author{
D.S. Thorat ${ }^{1 *}$, A.P. Magar ${ }^{1}$, Manoj Kumar ${ }^{1}$, B.B. Gaikwad ${ }^{2}$ and V. Bhushana Babu ${ }^{1}$ \\ ${ }^{1}$ Agricultural Mechanization Division, ICAR-CIAE, Bhopal, India \\ ${ }^{2}$ ICAR-NIASM, Baramati, India \\ *Corresponding author
}

\begin{abstract}
A B S T R A C T
A study was conducted to evaluate experimental set up for site specific application of neem coated granular urea. This was aimed to enhance fertilizer use efficiency, saving in input cost and reduced environmental degradation due to excessive use of fertilizer. The lab set up was developed based on design requirement consisted of fluted roller metering mechanism, mechanically actuated fertilizer dispensing system, fertilizer box and chain conveying arrangement for fixing cotton plant stem. A mechanical arrangement senses plant and fertilizer delivery system applies fertilizer to target plant. The fertilizer dispensing system's actuating arm can be opened at force as low as $70 \mathrm{gm}$. Physical properties of neem coated granular urea were measured. Fertilizer box was provided with $45^{\circ}$ side slope for free flow urea on the basis of angle of repose. The experimental set up has been tested over sticky belt to investigate optimum operating parameters for site specific application of neem coated urea. Simulated/Crop condition was created using cotton plant stems fixed over chain conveyor at a spacing of $60 \mathrm{~cm}$. The setup was evaluated in terms of amount of urea delivered and length of band by varying exposure length of fluted roller $(8,16,24,32 \mathrm{~mm})$ and forward speed $(1.57,2.04,2.5$ and 3.1 $\mathrm{km} \cdot \mathrm{h}^{-1}$ ). Best performance was observed at forward speed between 1.57 to $2.5 \mathrm{~km} . \mathrm{h}^{-1}$.It was also found that percentage filling was observed between 155 to $189 \%$ as against theoretical values due to passive flow.SD and C.V. values for amount of urea delivered were ranged between $0.5-3.57$ and $10-16 \%$, respectively. Length of fertilizer band was observed in the range of 13 to $19 \mathrm{~cm}$ for selected forward speeds. Indicating that the developed setup can be used successfully for testing of site specific application of neem coated urea.
\end{abstract}

Keywords

Fertilizer

\section{Introduction}

Cotton is one of the most important cash crop of India and plays a dominant role in the industrial and agricultural economy of the country. India has the largest acreage $(12.85 \mathrm{~m}$ ha) under cotton at global level and has the productivity of $486 \mathrm{~kg}$ Lint/ha and ranks second in production (295 lakh bales) (480 lb. bales) or (66.2 m MT) after China during 2014-15 (Anon., 2017). India has a unique distinction of being the only country in the world to cultivate all four cultivable Gossypium species, G.arboretum, $\quad G$. herbaceum (Asian cotton), G. barbadense (Egyptian cotton) and G.hirsutum (American upland cotton) besides hybrid cotton. Cotton cultivation is practiced in different parts of 
India with different plant to plant (150$675 \mathrm{~mm})$ and row to row $(450-1500 \mathrm{~mm})$ spacing. The world fertilizer consumption has increased over 2 percent yearly from 2008 to 2012, equivalent to an increment of 19.3 million fertilizer nutrient tones (Anon., 2011). Fertilizer use on cotton in India has constantly increased over the past 10 years from $96 \mathrm{~kg} / \mathrm{ha}$ in 2002 to $222 \mathrm{~kg} / \mathrm{ha}$ in 2011 and continuing. The extraction of nutrients is enormous as cotton is a deep rooted crop. It is therefore important to replenish the soil nutrients through balanced fertilization for long term sustainability. In order to enhance the nutrient use efficiency it is important to apply nutrients at right time, in right quantity and by appropriate method. Nitrogen $(\mathrm{N})$ is the nutrient that is required most consistently and in larger amounts than other nutrients for cotton production (Hou et al., 2007). For rainfed cotton $\mathrm{N}$ fertilizer doses are1/3rd quantity each at 30, 60 and 90-days after sowing, whereas for irrigated cotton basal dose also may be applied (Dhar et al., 2010). In recent years, increasing nitrogen $(\mathrm{N})$ fertilizer costs and increased focus on greenhouse gas emissions have prompted greater attention to the efficient use of $\mathrm{N}$ fertilizers (Rochester et al., 2007).

Presently, manual broadcasting, side band placement and ring basin fertilizer application are the practices mainly followed in cotton crop at farmer's field. All these methods have certain demerits such as very time consuming, labour intensive, low fertilizer use efficiency and non-uniform application of fertilizer etc. Also, broadcasting of fertilizers, especially $\mathrm{P}$ and $\mathrm{K}$, results in fixation problems due to more soil contact and applied $\mathrm{N}$ is lost due to volatilization. It has been reported that only $40-50 \%$ of N (Acharya and Sharma, 2008)and $20-30 \%$ of P and K (Rowse and Stone, 1980) fertilizers are effectively used by the crops. It has been conclusively proved that placing any kind of fertilizer in a band $30-50 \mathrm{~mm}$ beside and $20-30 \mathrm{~mm}$ deep to the seed is safe and effective for most of the crops (Martin and Leonard, 1976; Kepner et al., 1987). Some fertilizer applicators were developed for band application in crops like sugarcane, soybean etc., which gave positive results (Mandal and Thakur, 2010). Many approaches have been investigated by different researchers to improve NUE by combining the plant sensing techniques and precision application of fertilizers. Site-specific fertilization can reduce fertilizer usage, improve crop production and protect environment (Zaman et al., 2006; Saleem et al., 2011). Also, fertilizer application in bare spots and weed patches can deteriorate water quality, promote weed growth and reduce profit. Site-specific fertilization using differential global positioning system (DGPS) guided prescription maps, have been reported for several cropping systems(Derby et al., 2007). In the present study, mechanical sensing and fertilizer dispensing system was tested in the laboratory for site specific application of neem coated urea.

\section{Materials and Methods}

\section{Cotton crop N fertilizer requirement}

Mainly there are three fertilizer doses of N, P, K (i.e. 100:50:50, 160:80:80 and 240:120:120) recommended for cotton crop depending on varieties (Straight or Hybrid) and growing condition (Irrigated or Rainfed). Nitrogen in three splits at sowing, squaring and peak flowering stages have been recommended.

\section{Experimental lab set up}

The experimental lab set up (Fig. 1) consisted of fertilizer box, fluted roller metering mechanism, plant sensing system, fertilizer dispensing unit and balance for urea weight measurement. Cotton plants at $60 \mathrm{~cm}$ spacing were simulated by fixing cotton plant stem over chain conveyor system. The set up was fixed over sticky belt and evaluated in terms 
of amount of urea delivered per plant and fertilizer band length at optimal operating parameters.

\section{Fertilizer box and metering unit}

A fertilizer box was fabricated of M.S. sheet having upper portion of rectangular shape (of size $230 \times 248 \times 100 \mathrm{~mm}$ ) and lower half of frustum pyramid shape (Top width- $230 \mathrm{~mm}$; Bottom width- $130 \mathrm{~mm}$; Depth-50 mm). Fertilizer box sides provided with slope of $45^{\circ}$ for smooth flow of urea. Fluted roller with 10 no. of flutes of diameter, $50 \mathrm{~mm}$ and effective length of $40 \mathrm{~mm}$ was selected. The fertilizer fluted rollers were made of cast aluminium of grade A-4 M.

\section{Chain conveyor system for plant simulation}

Two sprockets (each with no. of teeth 37) and chain conveyor mechanism for carrying plant stem were developed in order to simulate plant in lab condition to study site specific fertilizer delivery. However, for simulation plant spacing can be changed with the help of locking arrangement.

\section{Fertilizer dispensing system}

Fertilizer dispensing unit designed for mechanical sensing of plant for predetermined and precise delivery to targeted plant, skipping bare spaces. It consists of actuating arm which strikes with plant stem then actuates cut-off device provided with fertilizer dispensing system.

\section{Power transmission system}

Power transmission system designed in such way that plant carrying chain conveyor mechanism and sticky belt should be operated at same linear speed for correct simulation. Also, in order to achieve recommended $\mathrm{N}$ fertilizer delivery (Table 1), speed ratio of 1.97:1 was maintained with the help of different sizes of sprockets.

\section{Physical properties of neem coated urea Bulk density}

Bulk density is important for designing fertilizer box and metering capacity of fluted roller. It was measured with the help of cylindrical measuring cylinder of $400 \mathrm{ml}$ size. The measuring cylinder was filled with neem coated urea up to top and any excess amount scrapped-off. No separate or additional manual compaction was done (Fig. 2). The bulk density $\left(\rho b, \mathrm{~kg} . \mathrm{cm}^{-3}\right)$ was determined as a ratio of the mass of the bulk sample to the volume of the container (Suthar and Das, 1996).

\section{Angle of repose}

Angle of repose is crucial in relation to easy free flow of material through the fertilizer box. This was determined by using an angle of repose apparatus as shown in Figure 3. The apparatus is of conical shape with a sliding gate at the bottom and circular base of 450 $\mathrm{mm}$ diameter for material deposition. The apparatus was filled with neem coated urea, and the sliding gate at the bottom was slowly removed until it formed a cone on the circular base. The diameter and height of the cone formed was recorded. The angle of repose $(\theta)$ was calculated by using the following equation (Mohsenin, 1986)

$$
\theta=\tan ^{-1} \frac{2 H}{D}
$$

Where, $\mathrm{H}$ is the height of the cone $(\mathrm{cm})$ and $\mathrm{D}$ is the diameter of the cone $(\mathrm{cm})$.

\section{Coefficient of static friction}

The coefficient of static friction was determined with respect to three surfaces; plywood, galvanized iron and mild steel with painted surface. A wooden cube open at both ends was filled with the urea and placed on an adjustable tilting table such that the wooden cube does not touch the table surface. The 
tilting surface was raised gradually with proper care until the cube just started to slide down. The angle of the surface was read from a scale and the static coefficient of friction was taken as the tangent of this angle (Suthar and Das, 1996; Dutta et al., 1988; Singh and Goswami, 1996) (Fig. 4).

\section{Weight of neem coated urea grains in a single flute}

This was recorded to estimate amount of urea delivered in one revolution of fluted roller. Also, no. of grains that can be accommodated in a single flute were recorded (Fig. 5).

\section{Average grain diameter}

Uniformity in distribution of fertilizer depends on physical characteristics (i.e. variation in grain diameter) of material being metered. Therefore, average grain diameter was recorded with the help of digital Vernier calliper (Fig. 6).

\section{Experiment procedure, testing and calibration}

Evaluation procedure was carried out in terms of amount of urea delivered and length of band applied at different levels of independent parameters viz. exposure length of fluted roller $(8,16,24,32 \mathrm{~mm})$ and forward speed $\left(1.57, \quad 2.04, \quad 2.5\right.$ and $\left.3.1 \quad \mathrm{~km} . \mathrm{h}^{-1}\right)$. Trials conducted as per experimental plan and data recorded in PC with the help of terminal tool for further analysis. For calibration set up was operated for pre-determined revolutions of fluted roller and measurement was done for amount of urea delivered. In order to see the significance of results for amount of urea delivered and band length data were subjected to statistical analysis using SAS software (version 9.3).For data analysis purpose, symmetrical factorial experiment laid in completely randomized statistical design was used.

\section{Results and Discussion}

\section{Physical properties of neem coated urea}

Mean and standard deviation were calculated for each selected parameters. The average of bulk density, angle of repose, urea grain diameter, grain weight in single flute measured were $0.759 \pm 0.011 \mathrm{gm} / \mathrm{cc}, 26.22 \pm$ $1.18^{\circ}, 3.38 \pm 0.23 \mathrm{~mm}, \quad 1.46 \pm 0.04 \mathrm{~g}$, respectively. The coefficient of static friction with plywood, galvanized iron and mild steel with painted surface observed were $0.3177 \pm 0.0092,0.2868 \pm 0.0077$, and 0.3177 \pm 0.0092 , respectively.

\section{Urea delivery per plant basis (At exposure length of fluted roller, $24 \mathrm{~mm}$ )}

Performance of experimental lab setup was investigated for site specific application of neem coated granular urea in terms of amount of urea delivered to each plant at selected levels of exposure length of fluted roller (8, 16,24 , and $32 \mathrm{~mm}$ ) and forward speed (1.57, $2.05,2.5$ and $\left.3.1 \mathrm{~km} \cdot \mathrm{h}^{-1}\right)$. Therefore, in order to present results on urea delivery per plant basis, exposure length of fluted roller $24 \mathrm{~mm}$ selected and results shown in Figure 7 (a, b,c, d) for selected forward speeds. Each bar in graph represents amount of urea delivered to single plant spaced at $60 \mathrm{~cm}$. It reveals from Figure 7 (a, b, c, d), as the forward speed increased from 1.57 to $3.1 \mathrm{~km} . \mathrm{h}^{-1}, \mathrm{C}$.V. values of urea delivery increased from12.16-20.42 per cent. Increase in C.V. values attributed to variation in fertilizer properties, improper filling of fluted roller and inherent cyclic variations and limitation of cut-off device relatively at higher speed. Similarly, Southwell and Samuel (1967) also found the variations between units that amounted to 20 to $31 \%$ from the mean for stationary opening distributor, 8 to $27 \%$ with star-wheel feed, and 6 to $17 \%$ with spiral-coil distributor. 
Table.1 Urea requirement per plant basis at different recommended doses

\begin{tabular}{|c|c|c|c|c|}
\hline $\begin{array}{c}\text { Dose of } \\
\text { nitrogen, } \\
\text { kg/ha }\end{array}$ & $\begin{array}{c}\text { Amount of } \\
\text { nitrogen per } \\
\text { split, kg ( 3 splits } \\
\text { in season) }\end{array}$ & $\begin{array}{c}\text { Amount of } \\
\text { urea per } \\
\text { split, kg }\end{array}$ & $\begin{array}{c}\text { Total amount } \\
\text { of urea per } \\
\text { plant, gm }\end{array}$ & $\begin{array}{c}\text { Amount to be } \\
\text { delivered per } \\
\text { pass to single } \\
\text { plant, gm }\end{array}$ \\
\hline 240 & 80 & 173.91 & 12.52 & 6.26 \\
\hline 160 & 53.33 & 115.94 & 8.35 & 4.17 \\
\hline 100 & 33.33 & 72.46 & 5.22 & 2.61 \\
\hline
\end{tabular}

Table.2 Analysis of variance of amount of urea delivered

\begin{tabular}{|l|r|r|r|r|r|}
\hline Source & DF & Type III SS & Mean Square & F Value & Pr $>$ F \\
\hline Forward speed & 3 & 6.6046563 & 2.2015521 & 18.33 & $<.0001$ \\
\hline Exposure Length & 3 & 682.5855729 & 227.5285243 & 1894.24 & $<.0001$ \\
\hline FS*EL & 9 & 3.7773188 & 0.4197021 & 3.49 & 0.0046 \\
\hline Error & 30 & 3.6034833 & 0.1201161 & & \\
\hline Corrected Total & 47 & 699.5170813 & & & \\
\hline
\end{tabular}

Table.3 Comparison between the parameters by using DMRT

\begin{tabular}{|l|l|l|l|}
\hline \multicolumn{4}{|c|}{$\begin{array}{l}\text { Means with the same letter } \\
\text { are not significantly different (Amount of urea, g) }\end{array}$} \\
\hline $\begin{array}{l}\text { Forward } \\
\text { Speed }\end{array}$ & Mean & $\begin{array}{l}\text { Exposure } \\
\text { Length }\end{array}$ & Mean \\
\hline $\mathbf{1 . 5 7}$ & $9.6433^{\mathbf{a}}$ & 8 & $4.5058^{\mathbf{a}}$ \\
\hline $\mathbf{2 . 0 4}$ & $9.2883^{\mathbf{b}}$ & 16 & $6.8817^{\mathbf{b}}$ \\
\hline $\mathbf{2 . 5}$ & $8.6108^{\mathbf{c}}$ & 24 & $11.0125^{\mathbf{c}}$ \\
\hline $\mathbf{3 . 1}$ & $9.1750^{\mathbf{b}}$ & 32 & $14.3175^{\mathbf{d}}$ \\
\hline
\end{tabular}

Table.4 Analysis of variance of band length

\begin{tabular}{|l|r|r|r|r|r|}
\hline Source & DF & Type III SS & Mean Square & F Value & Pr > F \\
\hline Forward speed & 3 & 129.8200000 & 43.2733333 & 110.64 & $<.0001$ \\
\hline Exposure Length & 3 & 13.4866667 & 4.4955556 & 11.49 & $<.0001$ \\
\hline FS*EL & 9 & 13.1133333 & 1.4570370 & 3.73 & 0.0031 \\
\hline Error & 30 & 11.7337500 & 0.3911250 & & \\
\hline Corrected Total & 47 & 169.2266667 & & & \\
\hline
\end{tabular}


Table.5 Comparison between the parameters by using DMRT

\begin{tabular}{|l|l|l|l|}
\hline \multicolumn{4}{|c|}{$\begin{array}{c}\text { Means with the same letter } \\
\text { are not significantly different (Band length) }\end{array}$} \\
\hline $\begin{array}{l}\text { Forward } \\
\text { speed }\end{array}$ & \multicolumn{2}{|c|}{$\begin{array}{l}\text { Mean } \\
\text { Exposure }\end{array}$} & $\begin{array}{l}\text { Mean } \\
\text { Length }\end{array}$ \\
\hline $\mathbf{1 . 5 7}$ & $13.7500^{\mathbf{a}}$ & 8 & $15.3500^{\mathbf{a}}$ \\
\hline $\mathbf{2 . 0 4}$ & $15.3500^{\mathbf{b}}$ & 16 & $15.6667^{\mathbf{a}}$ \\
\hline $\mathbf{2 . 5}$ & $16.8000^{\mathbf{c}}$ & 24 & $16.6667^{\mathbf{b}}$ \\
\hline $\mathbf{3 . 1}$ & $18.1667^{\mathbf{d}}$ & 32 & $16.3833^{\mathbf{b}}$ \\
\hline
\end{tabular}

Fig.1 Experimental set up with data recording arrangement

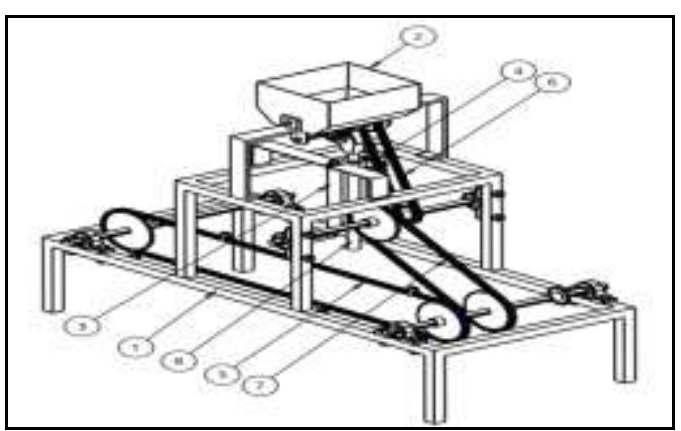

(a)

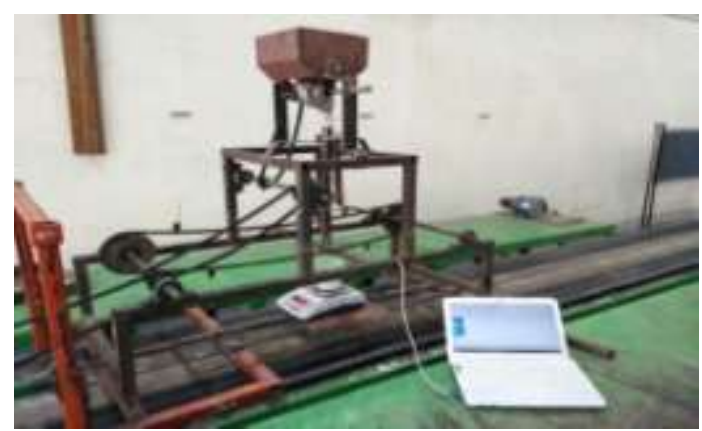

(b)

1. Setup frame, 2. Fertilizer box, 3. Fertilizer dispensing unit, 4. Spring of dispensing unit, 5. Chain conveyor, $6 \& 7$. Chain and sprocket 8 . Fertilizer delivery pipe

Fig.2 Measurement of bulk density

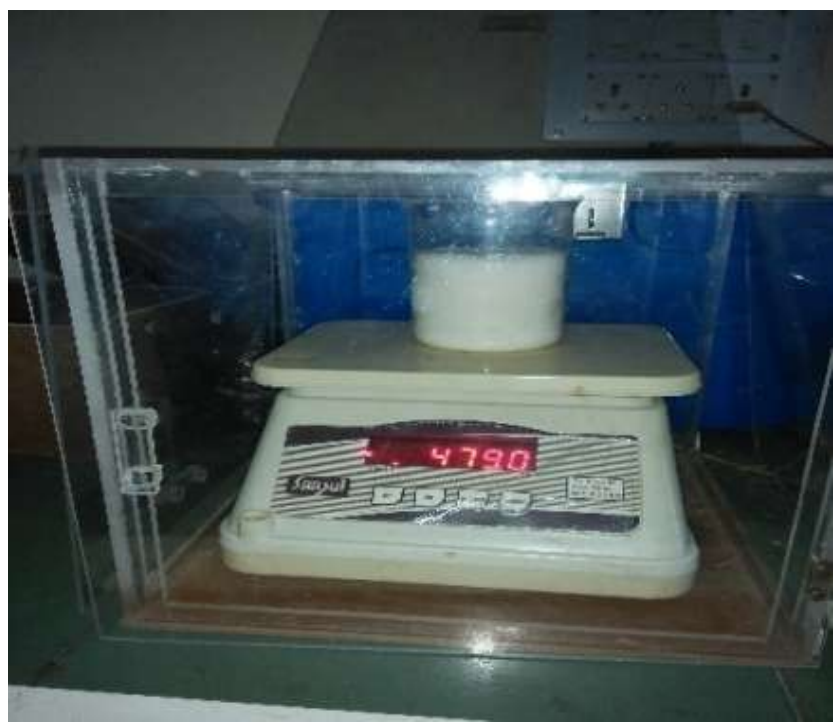


Fig.3 Measurement of angle of repose

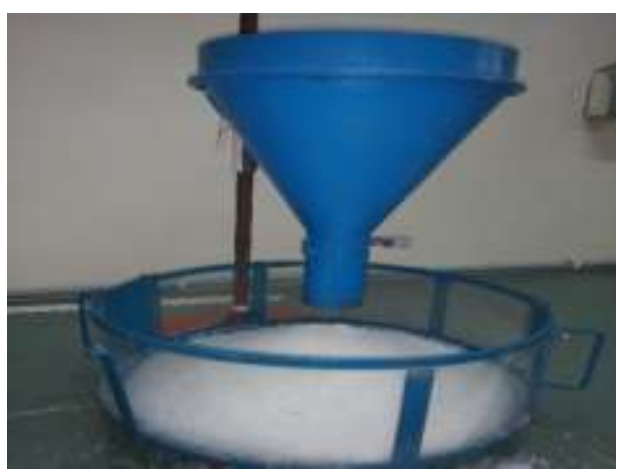

Fig.4 Measurement of coefficient of friction

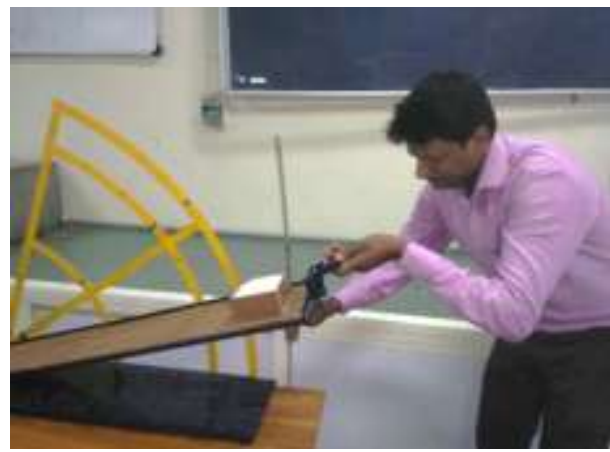

Fig.5 Urea grains in single flute of fluted roller
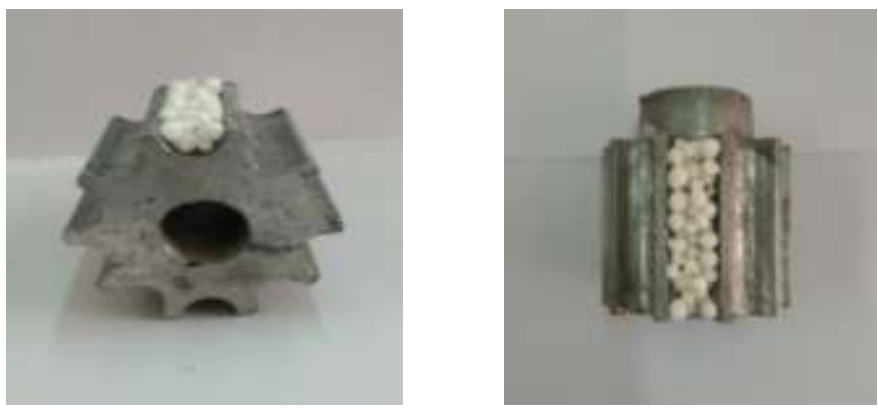

Fig.6 Measurement of average urea grain diameter

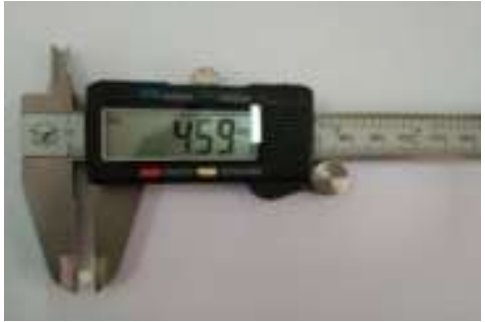


Fig.6 Measurement of average urea grain diameter

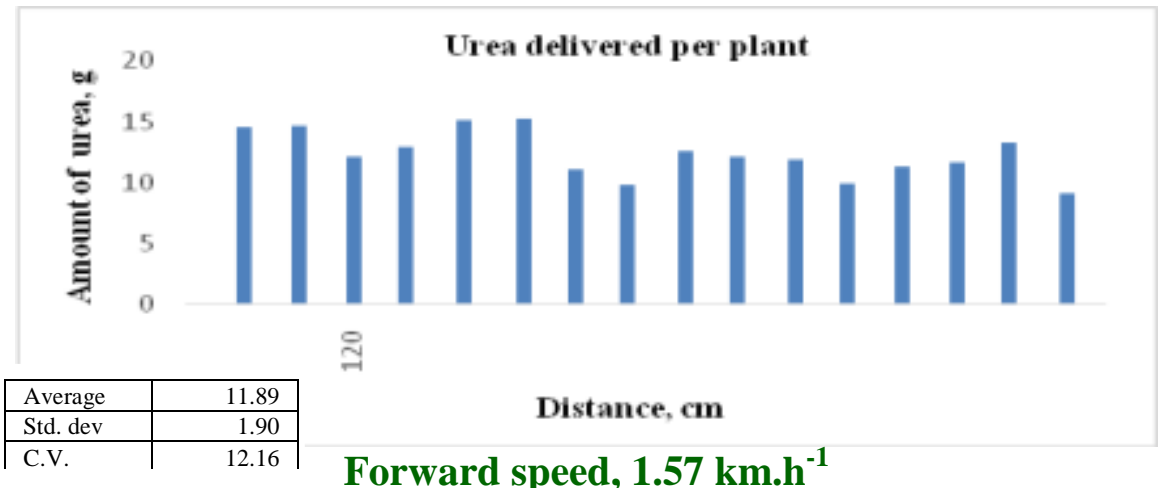

(a)

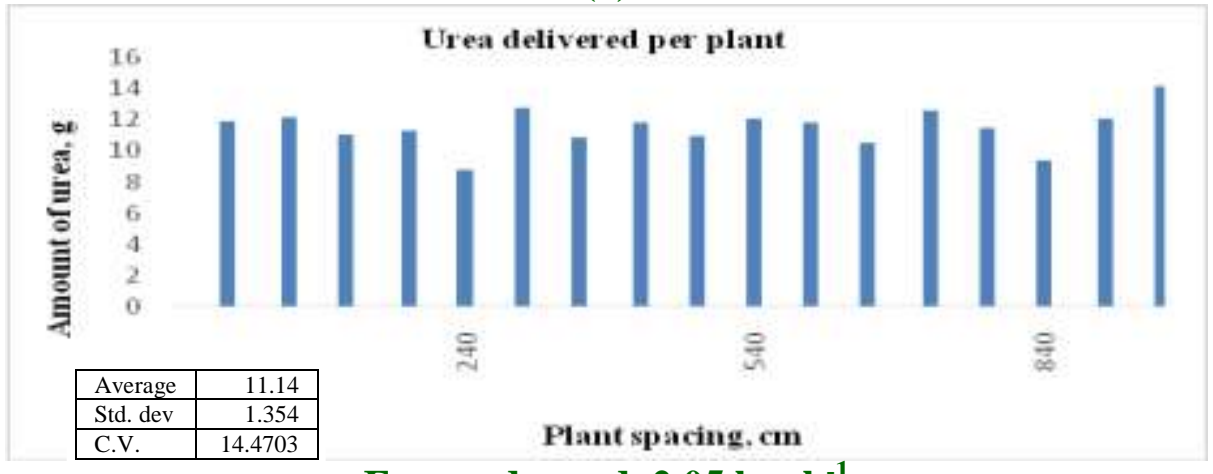

Forward speed, $2.05 \mathrm{~km} . \mathrm{h}^{-1}$

(b)

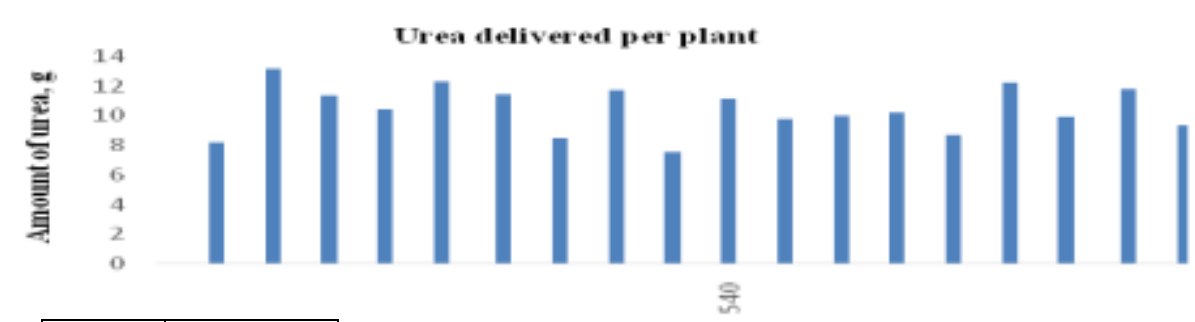

\begin{tabular}{|l|r|}
\hline Average & 9.98 \\
\hline Std. dev & 1.444 \\
\hline C.V. & 16.00 \\
\hline
\end{tabular}

Plant spacing, cm

Forward speed, $2.5 \mathrm{~km} . \mathrm{h}^{-1}$

(c)

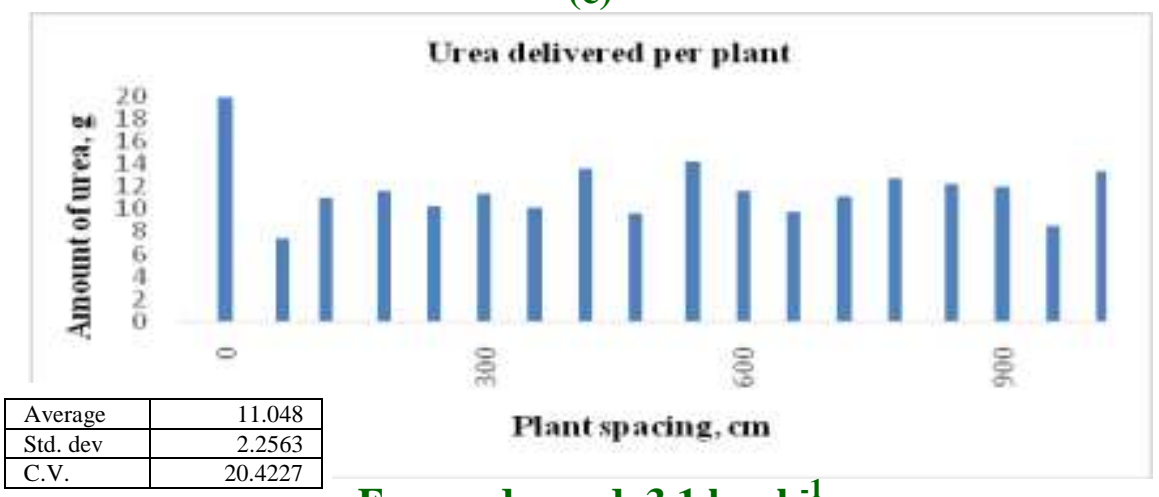

Forward speed, $3.1 \mathrm{~km} \cdot \mathrm{h}^{-1}$

(d) 
Fig.8 Effect of forward speed on urea delivery

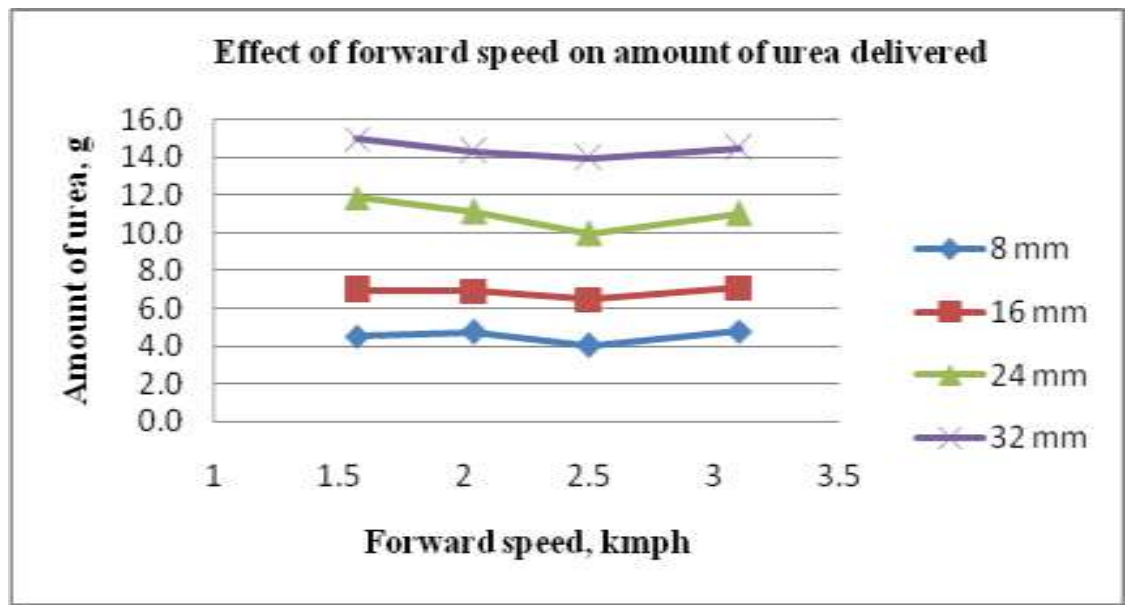

Fig.9 Effect of exposure length of fluted roller on urea delivery

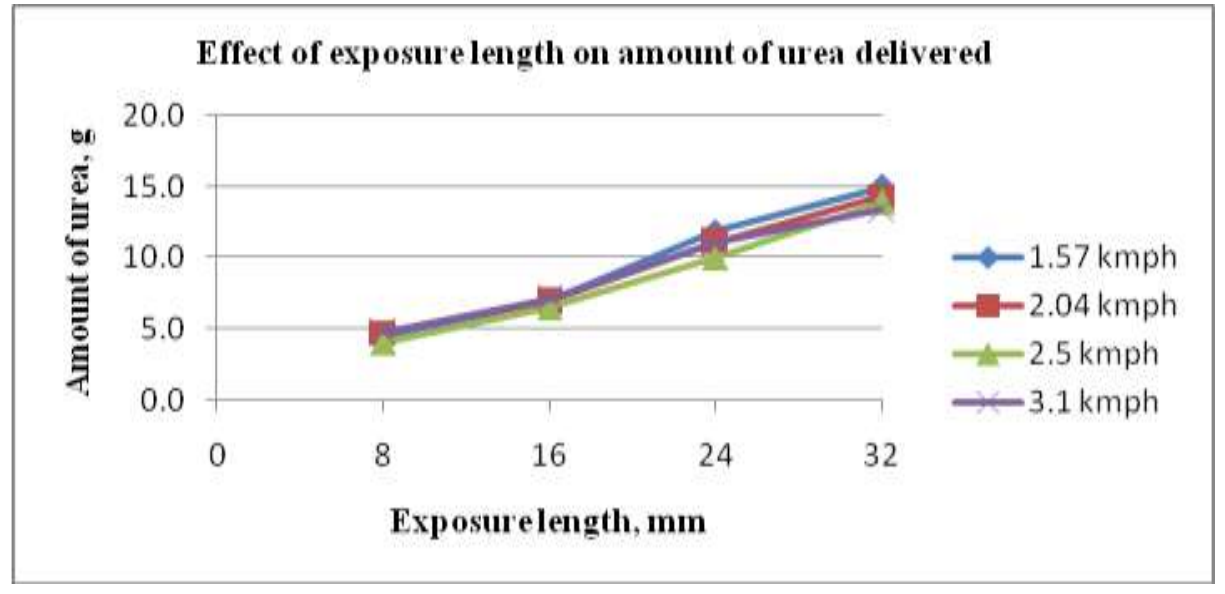

Fig.10 Effect of forward speed on band length

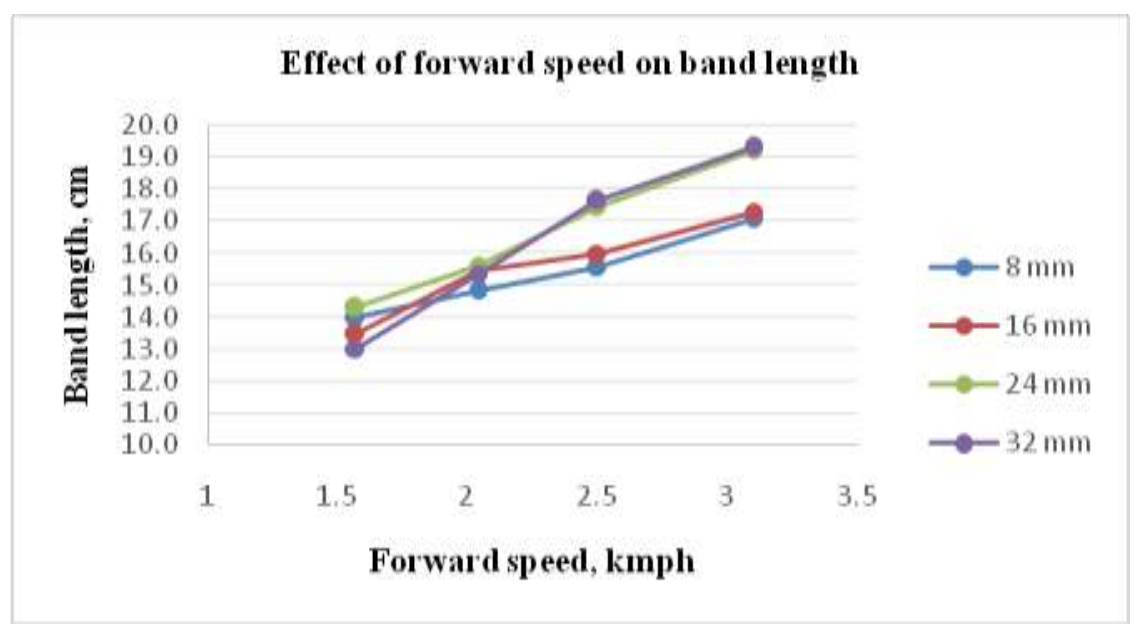


Fig.11 Effect of exposure length of fluted roller on band length

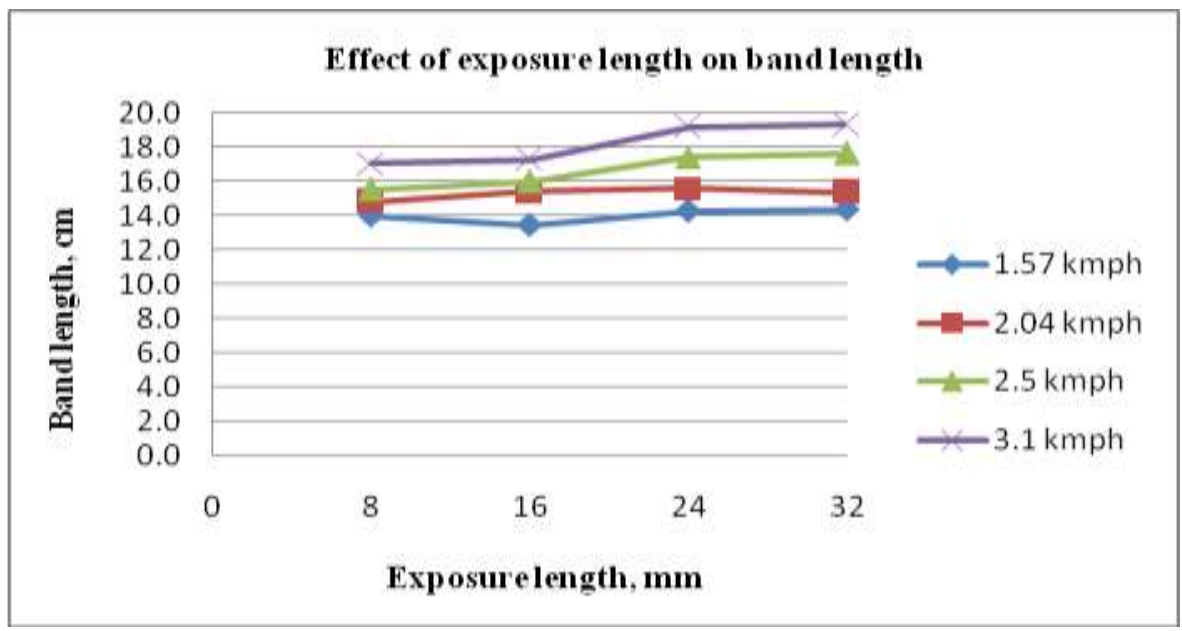

\section{Effect of operational parameters on}

\section{Amount of neem coated urea delivered}

The results of test analysis indicated that forward speed, exposure length of fluted roller and interaction effect of both were found to be significant at $1 \%$ level of significance (Table 2). Duncan's Multiple Range Test (DMRT) was applied to each parameter and the comparisons were given in table (Table 3). DMRT infers that effect of forward speed on amount of urea delivered was found significant between 1.57, 2.04 and $2.5 \mathrm{~km} . \mathrm{h}^{-1}$ values. However, forward speed 2.04 and $3.1 \mathrm{~km} \cdot \mathrm{h}^{-1}$ were found to be nonsignificant (Table 3). For exposure length DMRT indicated that all the exposure lengths were found to be significant. This analysis indicates that as we increase the forward speed the amount of urea delivered decreases upto 2.5 and then again increased up to 3 $\mathrm{km} \cdot \mathrm{h}^{-1}$ (Fig. 8). This was due to increase in forward speed which in turn increases rpm of fluted roller (from 25 to $42 \mathrm{rpm}$ ), that reduces filling percentage of fluted roller. Nathan et al. (2000) reported that cell fill of rollers decreases with increase in speed of fluted roller for U-shape fluted roller. However, the results obtained from site specific delivery approach, indicated that $3.1 \mathrm{~km} \cdot \mathrm{h}^{-1}$ urea delivery increased as mechanical cut-off of fertilizer dispensing system did not get sufficient time to close completely results in continuous band application instead of site specific application. There was significant change in amount of urea delivery by varying exposure length of fluted roller (Figure 9). Many researchers used exposure length of fluted roller as means to change delivery of material being metered. Therefore, fertilizer delivery rate can be changed by adjusting exposure length of fluted roller instead of changing speed ratio for obtaining significant results.

\section{Band length}

The effect of FS, EL of fluted roller and interaction on band length indicated that all the main effect and interactions were found significant at $1 \%$ level of significance (Table 4). Duncan's Multiple Range Test (DMRT) comparisons indicated that all the forward speeds were found to be significant (Table 5), while for exposure length first two levels i.e. $8 \mathrm{~mm} \& 16 \mathrm{~mm}$ and other two i.e. $24 \mathrm{~mm} \&$ $32 \mathrm{~mm}$ remained non-significant. This analysis indicates that as we increase the forward speed the band length increases (Figure 10). This was due to for increased forward speed, sticky belt cover more 
distance till urea delivery through fertilizer tube. The comparisons of exposure length of fluted roller indicated that increase in band length was non-significant between 8 \& 16 $\mathrm{mm}$ and, $24 \mathrm{~mm} \& 32 \mathrm{~mm}$. But, band length in case of $24 \& 32 \mathrm{~mm}$ increased significantly as compare to $8 \mathrm{~mm} \mathrm{\&} 16 \mathrm{~mm}$ due to increased amount of urea in cut-of device of fertilizer dispensing system (Figure 11).

It can be concluded from this study that a novel mechanism for site specific delivery was successfully tested in the laboratory that gave better results. Coefficient variation (C.V) values for amount of urea delivered were found in the acceptable range 12.16$20.42 \%$ for all combinations of independent parameters. The urea grain diameter size was ranged between 1.87 to $5.21 \mathrm{~mm}$, which might be one of the contributing factors for variation in urea delivery amount. Amount of neem coated urea delivered influenced by both forward speed of machine and exposed length of fluted roller, but later affects more. The time required by triggering and fertilizer dispensing mechanism to operate once was observed between $0.8-0.9 \mathrm{~s}$. The developed mechanism can be satisfactorily operated upto forward speed $2.5 \mathrm{~km} \cdot \mathrm{h}^{-1}$. The neem coated urea delivered per plant basis were in the range of 4.5 to $14 \mathrm{~g}$ for exposure lengths 8 $\mathrm{mm}, 16 \mathrm{~mm}, 24 \mathrm{~mm}$ \& $32 \mathrm{~mm}$, which matches with recommendations for cotton crop. Similarly, both forward speed of machine and exposure length of fluted roller have affected significantly on length of fertilizer band. However, forward speed of machine affects more than exposed length of fluted roller. The setup could able to deliver fertilizer band of length ranged from 13-19 $\mathrm{cm}$. Therefore, it reveals from this study, site specific application can be done at forward speed between 1.5 and $2.5 \mathrm{~km} \cdot \mathrm{h}^{-1}$. Also, desired application rate of neem coated urea can be delivered by varying exposed length of fluted roller.

\section{References}

Acharya C L., Sharma A R. 2008. Integrated input management for improving nitrogen use efficiency and crop productivity. Indian J. Fert., 4(2), 3340, 43-50.

Anon. 2011. Current World Fertilizer Trends and Outlook to 2015. FAO. Food and Agriculture Organization of the United Nations Rome.

Anon.2017. USDA Report, Cotton: World Markets and Trade. Foreign Agricultural Service Pp-9. Retrieved form

https://apps.fas.usda.gov/psdonline/circ ulars/cotton.pdf

Derby N E., Casey F X M., Franzen D E. 2007. Comparison of nitrogen management zone delineation methods for corn grain yield. Agron. J. 99: 405414.

Dhar M., Krishna P V., Roy R. 2010. Manual on better management practices for cotton cultivation, WWF-India, 172-B, Lodi Estate, New Delhi 110003, Pp-7.

Dutta S K., Nema V K., Bhardwaj R K. 1988. Physical properties of gram. Journal of Agricultural Engineering Research, 39, 259-268.

Hou Z., Li P., Li B., Gong Z., Wang Y. 2007. Effects of fertigation scheme on $\mathrm{N}$ uptake and $\mathrm{N}$ use efficiency in cotton. Plant Soil 290, 115-126.

Kepner R A., Bainer R., Barger E L. 1987. Principles of farm machinery. 1st Indian Ed. CRS Publishers and Distributors, Delhi, India.

Mandal S., Thakur T C. 2010. Design and development of subsoiler-cumdifferential rate fertilizer applicator. Agric Eng Int: CIGR Journal. Vol. 12, No.1.

Martin J H., Leonard W H O. 1976. Principles of field crop production. 3rd Ed. The Macmillan Co., London, 1118 
Mohsenin N N. 1986. Physical Properties of Plant and Animal Materials (2nd Edn). Gordon and Breach Science Publishers: New York.

Nathan S K., Singh B., Thakur T C. 2000. Laboratory studies on performance of positive feed metering devices for band placement of fertilizers. Journal of Agricultural Engineering, Vol. 37 (2), $1-14$.

Rochester I., O’Halloran J., Maas S., Sands D., Brotherton E. 2007. Monitoring nitrogen use efficiency in your region. Aust. Cotton grower 28 (4), 24-27.

Rowse H R., Stone D A. 1980. Deep cultivation of a sandy loam. I. Effects on growth, yield and nutrient content of potatoes, broad beans, summer cabbage and red beet in 1977. Soil Tillage Res., 1(1), 57-68.

Saleem, S R., Zaman Q U., Shumann A W., Madani A., Percivel D C., Farooque A A., Khan F S., Read S. 2011. Impact of
Variable Rate Fertilization on Groundwater Contamination in Wild Blueberry Cropping System. ASABE Paper No. 1110631.

Singh K K., Goswami T K. 1996. Physical properties of cumin seed. Journal of Agricultural Engineering Research, 64, 93-98.

Southwell P H Samuel J. 1967. Accuracy of fertilizer metering by full-width machines. Trans. ASAE, 10(1),,62-65.

Suthar S H., Das S K. 1996. Some physical properties of Karingda seeds. Journal of Agricultural Engineering Research, 65: 15-22.

Zaman Q U., Schumann A W., Shibusawa S. 2006. Impact of Variable Rate Fertilization on Nitrate Leaching in Citrus Orchards. In: D. J. Mulla, (ed.), Proc. of the $8^{\text {th }}$ Int. Conf. on Precision Agriculture, pp. 15-20. ASA, CSSA, and SSSA. Madison, WI.

\section{How to cite this article:}

Thorat, D.S., A.P. Magar, Manoj Kumar, B.B. Gaikwad and Bhushana Babu, V. 2019. Site Specific Application of Neem Coated Urea for Cotton Crop- A Lab Study. Int.J.Curr.Microbiol.App.Sci. 8(10): 1989-2000. doi: https://doi.org/10.20546/ijcmas.2019.810.232 